\title{
Comparative Study on Effect of Microbial Cultures on Soil Nutrient Status and Growth of Spinach Beet in Polluted and Unpolluted Soils
}

\author{
Alavala Uma Rajashekhar ${ }^{1}$, R. Subhash Reddy ${ }^{1}$, M. Chandini Patnaik ${ }^{2}$ \\ and K. Damodara Chari ${ }^{1^{*}}$
}

${ }^{1}$ Department of Agricultural Microbiology and Bioenergy, Professor Jayashankar Telangana State Agricultural University, Rajendranagar, Hyderabad-500030, India

${ }^{2}$ AICRP on Micronutrients Soil and Plants, Telangana, Professor Jayashankar Telangana State Agricultural University, Rajendranagar, Hyderabad-500030, India

*Corresponding author

\begin{tabular}{|l|}
\hline Ke y w or d s \\
Microbial culture, \\
Pseudomonas, \\
VAM, Polluted \\
soils, Unpolluted \\
soils, Nutrient \\
status, Plant growth. \\
\hline Article Info \\
\hline $\begin{array}{l}\text { Accepted: } \\
\text { 12 March } 2017 \\
\text { Available Online: } \\
\text { 10 April } 2017\end{array}$ \\
\hline \hline
\end{tabular}

In this present studied poly bag experiment was conducted following complete randomized block design with 12 treatments and three replications. Polluted Soil with supply of fresh water, Unpolluted soil with supply of fresh water, Unpolluted soil with supply of polluted water. The results of pot culture were reveals that the Nitrogen availability was highest in $\mathrm{T}_{3}\left(140.65 \mathrm{kgha}^{-1}\right)$ and lowest in $\mathrm{T}_{8}\left(116.79 \mathrm{kgha}^{-1}\right)$ at harvesting stage, phosphorus uptake was found in the treatment $T_{3}\left(43.34 \mathrm{kgha}^{-1}\right)$ and Increasing soil phosphorus content due to the application of inorganic fertilizers in polluted soils, increased the nutrient availability in the soil, highest potassium uptake was observed in $T_{7}\left(241.26 \mathrm{~kg} \mathrm{ha}^{-1}\right)$ in un polluted soils application of fresh water. Application of microbial cultures had significant effect on nitrogen, phosphorus potassium uptake in spinach beet in the different pot culture treatments. The treatment $\mathrm{T}_{8}\left(70.03 \mathrm{~g}_{\text {plant }}{ }^{-1}\right)$ comprising RDF+FYM+VAM and Pseudomonas showed highest values at $30 \mathrm{DAS}, 60 \mathrm{DAS}$ in unpolluted soils over other treatments. Among all the treatments, $\mathrm{T}_{8}$ comprising RDF, FYM, VAM and Pseudomonas was showed highest dry weight of leaf per plant at 30 DAS \& 60 DAS in unpolluted soils.

\section{Introduction}

Soil contamination due to the disposal of industrial and urban wastes generated by human activities has become a major problem and an environmental concern. Controlled and uncontrolled disposal of wastes to agricultural soil are responsible for the migration of contaminants into non contaminated sites. Because of industrialization and urbanization, there is no much land is available for urban farming in and around Mumbai. Wherever the small lands are available as open space, unused lands, barren lands etc are contaminated by heavy metals which come through industrial waste disposal.

Microorganisms play a unique role in the soil ecosystem, because of their contributions to soil fertility. These are responsible for mineralization of nutrients, decomposition, and degradation or transformation of toxic compounds. The biological agents i.e. yeast, fungi or bacteria are used to remove toxic waste from environment (Vessey, 2003). Hence, microbial bioremediation is the most 
effective tool to manage the polluted environment and recover contaminated soil.

Vegetables are an important part of human's diet. In addition to a potential source of important nutrients, vegetables constitute important functional food components by contributing protein, vitamins, iron and calcium which have marked health effects. Amongst all the vegetables, the leafy vegetables have a very high protective food value. They are rich in mineral and hence can be called as "Mines of minerals".

Vitamin $\mathrm{A}$ and $\mathrm{C}$ are present in abundant quantities. It is a widely grown leafy vegetable. It is rich and cheap source of vitamin A, iron, essential amino acids Ascorbic acid etc. Beside this, soft fibrous matter is specially in providing necessary roughage in diet. Vegetables, especially those of leafy vegetables grown in heavy metals contaminated soils, accumulate higher amounts of metals than those grown in uncontaminated soils because of the fact that they absorb these metals through their leaves. Majority of the land resources were found to be uncultivable, as they were heavily contaminated with heavy metals. If the microbial bioremediation is proved to be effective, then the land resources can be preserved with good fertility, so that the farmers can be benefited by using these remediated soils for cultivation.

The crop benefiting microbial inoculants generally called as bioinoculants, help in augmenting the crop productivity through effective mobilization of major plant nutrients like $\mathrm{N}, \mathrm{P}$ and $\mathrm{K}$ and other minor nutrients needed by the crop. These beneficial microorganisms are also known to secrete plant growth promoting substances like IAA, GA, cytokinins, vitamins for the improvement of crop growth, yield and for quality produce (Ajay kumar et al., 2014). Mycorrhizal Fungi
(AMF) is widespread throughout the world and found in the majority of terrestrial ecosystems (Smith and Read, 2008). AMF can be integrated in soil management to achieve low-cost sustainable agricultural systems. AMF can reduce soil erosion by bringing together micro aggregates of soil particles to form macro aggregates (Miller and Jastrow, 1994). They are the obligate symbionts that can improve plant growth by up taking $\mathrm{P}$ and help to absorb $\mathrm{N}, \mathrm{K}, \mathrm{Ca}, \mathrm{S}$, $\mathrm{Cu}$, and $\mathrm{Zn}$ (Jiang et al., 2013); produce glomalin (Guo et al., 2012); increasing resistance to pests and soil borne diseases

\section{Materials and Methods}

\section{Soil samples and soil characteristics}

Soil samples of polluted and unpolluted soils were collected before sowing and analysed for the physical $(\mathrm{pH}, \mathrm{EC}$, and particle size and chemical characters like NPK and OC parameters) and microbiological properties by adopting standard procedures at Department of Agricultural Microbiology and Bio-energy and Department of Soil Science and Agricultural Chemistry, College of Agriculture, Rajendranagar, PJTSAU, Hyderabad.Water samples were also analyzed before sowing of crop in polluted and unpolluted soils (Table 1).

\section{Crop details}

The pot culture experiment was conducted at Department of Agricultural Microbiology and Bioenergy during 2012-13. For this investigation leafy vegetable crop, spinach beet, Pusa Jyothi variety was sown in pot experiments followed completely randomized block design with four treatments and three replications. Microbial cultures (Pseudomonas, VAM) collected from our laboratory 


\section{Experiment details}

\section{Treatments}

The treatments for poly bag experiment were fixed as twelve treatments each treatment with three replications was designed. All three replications were used to record observations on yield, quality parameters of spinach around 30 and 60 days after sowing.

In this context of pot culture experiment having twelve treatments and followed statistical design in this treatment subdivided into three parts: polluted soil with supply of fresh water, unpolluted soil with supply of fresh water and unpolluted soil with supply of polluted water. Polluted soil with supply of fresh water have T1: SF Soil+FYM@12 t/ha, T2: SF Soil + FYM + VAM + Pseudomonas, T3: SF Soil + RDF, T4: SF Soil + RDF + FYM + VAM + Pseudomonas. Unpolluted soil with supply of fresh water, have T5: Soil + FYM, T6: Soil + FYM + VAM + Pseudomonas, T7: Soil + RDF, T8: Soil + $\mathrm{RDF}+\mathrm{FYM}+\mathrm{VAM}+$ Pseudomonas. Unpolluted soil with supply of polluted water, have T9: Soil + FYM, T10: Soil+ FYM + VAM + Pseudomonas, T11: Soil + RDF, T12: Soil + RDF + FYM + VAM + Pseudomonas.

\section{Preparation of poly bags mixture}

The cleaned poly bags were filled with $8 \mathrm{~kg}$ soil and this soil was mixed with chemical fertilizer (0.14: 0.24: $0.37 \mathrm{~g}$ poly bag $^{-1} \mathrm{NPK}$ ), farm yard manure (78.75 $\mathrm{g}$ poly $\mathrm{bag}^{-1}$ ) and Vesicular Arbuscular Mycorrhizae (100 to $150 \mathrm{~g}$ of infected propagules poly $\mathrm{bag}^{-1}$ ) according to the treatments which were neatly arranged in the net house.

\section{Chemical fertilizers}

Phosphorus and potassium @ 0.24 g poly bag ${ }^{1} \mathrm{P}_{2} \mathrm{O}_{5}$ and $0.37 \mathrm{~g}$ poly bag ${ }^{-1} \mathrm{~K}_{2} \mathrm{O}$ were applied through Di Ammonium Phosphate and Muriate of Potash respectively as basal application. Nitrogen was applied in the form of Urea@0.24 g poly bag ${ }^{-1}$ after germination and after 30 and 60 days after sowing. Farmyard manure was applied @ 78.75 g poly bag $^{-1}$ which was mixed with soil according to the treatments requirement. $\mathrm{EC}$ and $\mathrm{pH}$ of FYM were $0.95 \mathrm{dS} \mathrm{m}^{-1}$ and 7.59 respectively and $\mathrm{Ni}, \mathrm{Co}, \mathrm{Cd}$ content in FYM was 0.91, $0.20,0.01-0.02$ respectively.

\section{Seed sowing and maintenance}

The poly bags were sown with Pusa Jyothi variety of spinach beet at the rate of 20 seeds per poly bag. After germination, thinning was done and routine care was taken to protect the plants from pest and diseases.

\section{Results and Discussion}

\section{$\mathbf{N}, \mathbf{P}, \mathbf{K}$ content in soil}

\section{Available nitrogen $\left(\mathrm{kg} \mathrm{ha}^{-1}\right)$}

Application of microbial cultures had significant effect on nitrogen uptake and presented in table 2 .

Nitrogen availability was highest in $T_{3}$ $\left(140.65 \mathrm{kgha}^{-1}\right)$ and lowest in $\mathrm{T}_{8}\left(116.79 \mathrm{kgha}^{-}\right.$

$\left.{ }^{1}\right)$ at harvesting stage and these were significantly different with each other. Among all the treatments polluted soil with supply of fresh water treatments were found that significantly highest nitrogen content was observed in treatments in which $100 \%$ RDF are added.

\section{Available phosphorous (kg ha $\left.{ }^{-1}\right)$}

Application of microbial cultures had significant effect on phosphorus uptake and presented in table 2 .

The data on soil phosphorus uptake showed significantly different. Among all the 
treatments, significantly highest phosphorus uptake was found in the treatment $\mathrm{T}_{3}(43.34$ $\left.\mathrm{kgha}^{-1}\right)$ and followed by $\mathrm{T}_{1}\left(41.76 \mathrm{kgha}^{-1}\right), \mathrm{T}_{2}$ $\left(39.82 \mathrm{kgha}^{-1}\right), \mathrm{T}_{9}\left(39.11 \mathrm{kgha}^{-1}\right)$ and lowest phosphorus uptake recorded in $\mathrm{T}_{8}\left(36.31 \mathrm{kgha}^{-1}\right)$.

Increasing soil phosphorus content due to the application of inorganic fertilizers in polluted soil, increased the nutrient availability in the soil. The higher nitrogen and phosphorus in polluted soil could be the contribution of industrial pollutants towards $\mathrm{N}, \mathrm{P}$ only and not to $\mathrm{K}$.

Available potassium (kg ha $\left.{ }^{-1}\right)$

Application of microbial cultures had significant effect on potassium uptake and presented in table 3 .

Table.1 Physico-chemical properties of soil before sowing

\begin{tabular}{|c|l|c|c|}
\hline S. No. & \multicolumn{1}{|c|}{ Soil properties } & Polluted soil & Unpolluted soil \\
\hline & Physical properties & & \\
\hline 1 & Particle size analysis & & \\
\hline & Sand (\%) & 11.0 & 52.3 \\
\hline & Silt (\%) & 34.8 & 12.3 \\
\hline & Clay (\%) & Black soil & Black soil \\
\hline 2 & Textural class & 1.47 & 1.45 \\
\hline 3 & Bulk density $\left(\mathrm{g} \mathrm{cm}{ }^{-3}\right)$ & 2.64 & 2.63 \\
\hline & Chemical properties & & 7.6 \\
\hline 4 & Soil reaction $(\mathrm{pH})$ & 7.85 & 1.19 \\
\hline 5 & Electrical conductivity $\left(\mathrm{dSm}^{-1}\right)$ & 1.23 & 0.72 \\
\hline 6 & Organic Carbon $(\%)$ & 0.63 & 206 \\
\hline 7 & Available nitrogen $\left(\mathrm{kg} \mathrm{ha}^{-1}\right)$ & 225 & 40.5 \\
\hline 8 & Available phosphorus $\left(\mathrm{kg} \mathrm{ha}^{-1}\right)$ & 44.3 & 253 \\
\hline 9 & Available potassium $\left(\mathrm{kg} \mathrm{ha}^{-1}\right)$ & & \\
\hline
\end{tabular}


Table.2 Effect of microbial cultures on soil N P K (kg/ha) at harvesting stage (60 DAS) in polluted and unpolluted soils of spinach beet

\begin{tabular}{|c|c|c|c|}
\hline Treatments & $\mathbf{N}$ & $\mathbf{P}$ & $\mathbf{K}$ \\
\hline \multicolumn{4}{|c|}{ Polluted Soil with supply of fresh water } \\
\hline $\mathrm{T}_{1}-\mathrm{SF}$ Soil+FYM & 133.05 & 41.76 & 222.72 \\
\hline $\mathrm{T}_{2}$ - SF Soil+FYM+VAM+ Psuedomonas & 128.56 & 39.82 & 205.59 \\
\hline $\mathrm{T}_{3^{-}}$SF Soil +RDF & 140.65 & 43.34 & 231.57 \\
\hline $\mathrm{T}_{4}-\mathrm{SF}$ Soil+RDF+FYM+VAM+Psuedomonas & 120.66 & 38.44 & 195.40 \\
\hline \multicolumn{4}{|c|}{ Unpolluted soil with supply of fresh water } \\
\hline $\mathrm{T}_{5^{-}}$SF Soil +FYM+Psuedomonas & 120.89 & 38.15 & 229.33 \\
\hline $\mathrm{T}_{6^{-}}$SF Soil + FYM+ VAM+Psuedomonas & 119.67 & 37.63 & 212.56 \\
\hline $\mathrm{T}_{7}-\mathrm{SF}$ Soil+RDF & 123.30 & 38.6 & 241.26 \\
\hline $\mathrm{T}_{8}-\mathrm{SF}$ Soil+RDF+FYM+VAM+Psuedomonas & 116.79 & 36.31 & 204.85 \\
\hline \multicolumn{4}{|c|}{ Unpolluted soil with supply of polluted water } \\
\hline $\mathrm{T}_{9^{-}}$Soil+FYM & 128.04 & 39.11 & 237.59 \\
\hline $\mathrm{T}_{10^{-}}$Soil+FYM+VAM+Psuedomonas & 121.40 & 37.87 & 215.37 \\
\hline $\mathrm{T}_{11-}$-Soil+RDF & 123.54 & 38.3 & 230.28 \\
\hline $\mathrm{T}_{12}-$ Soil+RDF+FYM+VAM+Psuedomonas & 118.28 & 37.37 & 201.003 \\
\hline SE $\mathbf{m} \pm$ & 0.504 & 0.285 & 0.608 \\
\hline C.D at $5 \%$ & 1.47 & 0.832 & 1.775 \\
\hline
\end{tabular}


Table.3 Effect of microbial cultures on fresh weight at 30 and 60 DAS in polluted and unpolluted soils of spinach beet

\begin{tabular}{|c|c|c|}
\hline \multirow[t]{2}{*}{ Treatments } & \multicolumn{2}{|c|}{ Fresh weight of leaf/plant } \\
\hline & 30DAS & 30DAS \\
\hline \multicolumn{3}{|c|}{ Polluted Soil with supply of fresh water } \\
\hline $\mathrm{T}_{1}-\mathrm{SF}$ Soil+FYM & 30.48 & 46.48 \\
\hline $\mathrm{T}_{2}-\mathrm{SF}$ Soil+FYM+VAM+ Psuedomonas & 34.02 & 54.05 \\
\hline $\mathrm{T}_{3}-\mathrm{SF}$ Soil +RDF & 23.02 & 38.65 \\
\hline $\mathrm{T}_{4}-\mathrm{SF}$ Soil+RDF+FYM+VAM+Psuedomonas & 39.40 & 60.54 \\
\hline \multicolumn{3}{|c|}{ Unpolluted soil with supply of fresh water } \\
\hline $\mathrm{T}_{5}-$ SF Soil +FYM+Psuedomonas & 31.30 & 52.30 \\
\hline $\mathrm{T}_{6}$ - SF Soil + FYM+ VAM+Psuedomonas & 39.89 & 64.87 \\
\hline $\mathrm{T}_{7^{-}}$SF Soil+RDF & 26.61 & 40.32 \\
\hline $\mathrm{T}_{8}-\mathrm{SF}$ Soil+RDF+FYM+VAM+Psuedomonas & 41.63 & 70.03 \\
\hline \multicolumn{3}{|c|}{ Unpolluted soil with supply of polluted water } \\
\hline $\mathrm{T}_{9^{-}}$Soil+FYM & 26.40 & 38.12 \\
\hline $\mathrm{T}_{10^{-}}$Soil+FYM+VAM+Psuedomonas & 34.71 & 61.03 \\
\hline $\mathrm{T}_{11}$ - Soil+RDF & 28.82 & 50.37 \\
\hline $\mathrm{T}_{12}-$ Soil+RDF+FYM+VAM+Psuedomonas & 41.36 & 68.10 \\
\hline SE $\mathbf{m} \pm$ & 0.176 & 0.167 \\
\hline C.D at $5 \%$ & 0.513 & 0.488 \\
\hline
\end{tabular}


Table.4 Effect of microbial cultures on dry weight at 30 and 60 DAS in polluted and unpolluted soils of spinach beet

\begin{tabular}{|c|c|c|}
\hline \multirow[t]{2}{*}{ Treatments } & \multicolumn{2}{|c|}{ Dry weight of leaf/plant } \\
\hline & 30DAS & 30DAS \\
\hline \multicolumn{3}{|c|}{ Polluted Soil with supply of fresh water } \\
\hline $\mathrm{T}_{1}-\mathrm{SF}$ Soil+FYM & 4.05 & 2.84 \\
\hline $\mathrm{T}_{2-}$ SF Soil+FYM+VAM+Psuedomonas & 4.73 & 3.24 \\
\hline $\mathrm{T}_{3}-\mathrm{SF}$ Soil +RDF & 3.16 & 2.22 \\
\hline $\mathrm{T}_{4}-\mathrm{SF}$ Soil+RDF+FYM+VAM+Psuedomonas & 5.55 & 3.58 \\
\hline \multicolumn{3}{|c|}{ Unpolluted soil with supply of fresh water } \\
\hline $\mathrm{T}_{5}-\mathrm{SF}$ Soil $+\mathrm{FYM}+$ Psuedomonas & 4.62 & 2.93 \\
\hline $\mathrm{T}_{6}-\mathrm{SF}$ Soil + FYM+ VAM+Psuedomonas & 5.82 & 3.80 \\
\hline $\mathrm{T}_{7}-\mathrm{SF}$ Soil+RDF & 3.55 & 2.52 \\
\hline $\mathrm{T}_{8}-$ SF Soil+RDF+FYM+VAM+Psuedomonas & 6.62 & 4.17 \\
\hline \multicolumn{3}{|c|}{ Unpolluted soil with supply of polluted water } \\
\hline $\mathrm{T}_{9-}$ Soil+FYM & 3.47 & 2.55 \\
\hline $\mathrm{T}_{10}-$ Soil+FYM+VAM+Psuedomonas & 5.45 & 3.38 \\
\hline $\mathrm{T}_{11}-$ Soil+RDF & 4.55 & 2.86 \\
\hline $\mathrm{T}_{12}-$ Soil+RDF+FYM+VAM+Psuedomonas & 5.97 & 3.95 \\
\hline SE $\mathbf{m} \pm$ & 0.046 & 0.03 \\
\hline C.D at $5 \%$ & 0.133 & 0.103 \\
\hline
\end{tabular}

Among all the treatments, lowest potassium uptake was observed in $\mathrm{T}_{4}\left(195.40 \mathrm{~kg} \mathrm{ha}^{-1}\right)$ in polluted soil with application of fresh water and highest potassium uptake was observed in $\mathrm{T}_{7}\left(241.26 \mathrm{~kg} \mathrm{ha}^{-1}\right)$ in un polluted soils application of fresh water.

The treatments applied with $100 \%$ RDF $\left(\mathrm{T}_{1}\right.$, $\mathrm{T}_{5}, \mathrm{~T}_{11}$ ) through inorganic fertilizers recorded significantly highest soil potassium at harvest stage of the spinach crop. The treatment $T_{3}$ (231.57 $\mathrm{kg} \mathrm{ha}^{-1}$ ) was showed highest nitrogen and potassium values in polluted soils with application of fresh water than potassium and $\mathrm{T}_{7}\left(241.26 \mathrm{~kg} \mathrm{ha}^{-1}\right)$ treatment was showed highest potassium values in unpolluted soils with application of polluted water

\section{Leaf fresh weight $\left(\mathrm{g} \mathrm{plant}^{-1}\right)$}

The data presented revealed that the leaf fresh weight was significantly affected by different treatments with RDF, combination of inorganic, organic manures (FYM, and biofertilizer) at 30 DAS and 60 DAS of crop (Table 3).

The highest leaf fresh weight plant $^{-1}$ was recorded in treatment $T_{8}\left(41.63 \mathrm{~g}\right.$ plant $\left.^{-1}\right)$ than the rest of treatments at 30 DAS in unpolluted soils. The lowest leaf fresh weight per plant was showed in $\mathrm{T}_{3}\left(23.02 \mathrm{~g} \mathrm{plant}^{-1}\right)$ at $30 \mathrm{DAS}$ in polluted soils. The highest leaf fresh weight was observed in $T_{8}\left(70.03 \mathrm{~g} \mathrm{plant}^{-1}\right)$ and the lowest value observed in $\mathrm{T}_{9}$ (38.12 g plant $^{-1}$ ) at 60 DAS in unpolluted soil. It was observed that the treatment $\mathrm{T}_{8} \quad\left(70.03 \mathrm{~g}\right.$ plant $\left.^{-1}\right)$ comprising $\mathrm{RDF}+\mathrm{FYM}+\mathrm{VAM}$ and Pseudomonas showed highest values at 30 DAS, 60 DAS in unpolluted soils over other treatments.

\section{Leaf dry weight (g plant $\left.{ }^{-1}\right)$}

The data presented revealed that the leaf dry weight was significantly influenced by 
recommended dose of fertilizers, combination of inorganic, organic manures (FYM) and biofertilizers (VAM and Pseudomonas) at 30DAS and 60 DAS.

The highest leaf dry weight plant $^{-1}$ was observed in $\mathrm{T}_{8}\left(6.62 \mathrm{~g}\right.$ plant $\left.^{-1}\right)$ and lowest value in $\mathrm{T}_{3}\left(3.16 \mathrm{~g}_{\text {plant }}{ }^{-1}\right)$ was observed at 30 DAS (Table 4). The highest leaf dry weight was observed in $\mathrm{T}_{8}\left(4.17 \mathrm{~g} \mathrm{plant}^{-1}\right)$ and the lowest in $\mathrm{T}_{3}\left(2.22 \mathrm{~g} \mathrm{plant}^{-1}\right)$ at $60 \mathrm{DAS}$.

Among all the treatments, $\mathrm{T}_{8}$ comprising RDF, FYM, VAM and Pseudomonas was showed highest dry weight of leaf per plant at 30 DAS and 60 DAS in unpolluted soils. In same way, the lowest dry weight of leaf was found in $T_{3}$ at 30 and 60 DAS in polluted soils. Similar results were reported by Madhvi et al., (2014). It was reported that increased leaf area and leaf dry weight in spinach was due to application of chemical fertilizers along with organic manures and biofertilizers.

In conclusion, it was reported that increased leaf area and leaf dry weight in spinach was due to application of chemical fertilizers along with organic manures and biofertilizers. Recycling of wastes for elements; microorganisms abound in the soil and are critical to decomposing organic residues and recycling soil nutrients. Finally results showed that unpolluted soil with the supply of fresh water and microbial cultures was given good results comparatively with polluted soil with supply of fresh water and unpolluted soil with supply of polluted water.

\section{References}

Ajay Kumar, J., Rangaswamy, E., Shivabasu khanagoudar and Sreeramulu, K.R. 2014. Effect of Microbial Inoculants on the Nutrient Uptake and Yield of Beetroot (Beta vulgaris L.). Curr. Agri. Res. J., 2(2): 123-130.

Guo, H., X. He and Y. Li. 2012. Spatial distribution of arbuscular mycorrhiza and glomalin in the rhizosphere of Caragana korshinskii Kom in the Otindag sandy land, China. Afric. J. Microbiol. Res., 6: 5745-5753.

Jiang, W., G. Gou and Y. Ding. 2012. Influences of arbuscular mycorrhizal fungi on growth and mineral element absorption of chenglu hybrid bamboo seedlings. Pak. J. Bot., 45(1): 303- 310.

Madhavi, Y., Goud, P.V., Reddy, K.M. and Saidulu, A. 2014. Effect of different levels of vermicompost, castor cake, poultry manure and biofertilizers on growth and yield of Indian spinach (Beta vulgaris var. bengalensis). Crop Res., 37(1/3): 148-151.

Miller, R.M. and J.D. Jastrow. 2012. Vesicular arbuscular mycorrhizae and biogeochemical cycling, pp. 189-212. In: Mycorrhizae and Plant Health (Eds.): F.L. Pfleger and R.G. Linderman. APS Press, The American Phytopathol. Soc., St. Paul, Minnesota.

Smith, S.E. and Read, D.J. 2008. Mycorrhizal symbiosis. 3rd ed. San Diego, CA, USA: Academic Press.

Vessey, J.K. 2003. Plant growth promoting rhizobacteria as biofertilizers. Plant Soil, 255(1): 571-586,

\section{How to cite this article:}

Alavala Uma Rajashekhar, R. Subhash Reddy, M. Chandini Patnaik and Damodara Chari, K. 2017. Comparative Study on Effect of Microbial Cultures on Soil Nutrient Status and Growth of Spinach Beet in Polluted and Unpolluted Soils. Int.J.Curr.Microbiol.App.Sci. 6(4): 13861393. doi: https://doi.org/10.20546/ijcmas.2017.604.169 